UNRAM Law Review is licensed under a Creative Commons Attribution 4.0 International License, which permits unrestricted use, distribution, and reproduction in any medium, provided the original work is properly cited. p-ISSN: 2548-9267 | e-ISSN : 2549-2365, Open Access at : http://unramlawreview.unram.ac.id/index.php/ulr

\begin{tabular}{c|c|c|c|c|}
\hline Volume & Issue & Page & Oktober & p-ISSN: 2548-9267 \\
\hline 3 & 2 & $71-77$ & 2019 & e-ISSN : 2549-2365
\end{tabular}

\title{
Political Intervention in Indonesian Legislation
}

\author{
Muhammad Satria \\ Magister of Law of Law Faculty \\ University of Mataram \\ Email: muhammad.satria311295@gmail.com \\ Munajah \\ Magister of Law of Law Faculty \\ University of Mataram \\ E mail: Munajah@gmail.com \\ Sulistia Ningsih Rahayu \\ Magister of Law of Law Faculty \\ University of Mataram \\ E mail: Sulistianingsih@gmail.com \\ Suryadi \\ Magister of Law of Law Faculty \\ University of Mataram \\ E mail: Sunardi@gmail.com
}

\begin{abstract}
The purpose of this research discusses political intervention in legislation in Indonesia to examine the problems that occur in the process of making laws. Based on the problems examined by the author, the research method used is a normative research method. Normative legal research methods or library research methods are methods or methods used in legal research conducted by examining existing library materials. Law intervention results in the form of ratification of the agenda of the intervention, and the Articles then become the basis for activities that are detrimental to the people at large and are contrary to ideology, religion for the Indonesian people. Thus, the intervention of the Law harms the nation extensively.
\end{abstract}

Keywords: Intervention; Law; Political.

\section{INTRODUCTION}

The law is complex entity, covering diverse social reality, have many aspects, dimensions and phase. When compared to objects it like a jewel that every part of it will give a different impression for everyone to see or look at him. The law always draws attention to and becomes a discourse that is endlessly debated by scholars.

Emerge of variety of legal disciplines in addition to legal philosophy and jurisprudence, such as the theory of law, history of legal anthropology, and recent is growing the political law, it is indisputable proof of the truth of the above statement. Although each variety of legal disciplines can be addressed as an independent 
discipline, but not all of them work independently as indeed are all intertwined to another. That is the discipline of law does not have any meaning without involving other disciplines.

The politics law is one of the youngest disciplines of the law, compared to other classical legal disciplines such as legal history, legal sociology, legal anthropology, legal philosophy, etc., but that does not mean that the politics law does not have a strategic position as a science from axiological side was able to uncover the mysteries of the law as well as the disciplines of law that have been there before.

Interestingly, the politics law at the academics of the politics law has been recognized as one of the compulsory subjects at the postgraduate level of the Faculty of Law, although it does not yet have an established scientific structure. Ironically, even though it has become one of the compulsory subjects at postgraduate, the development of this discipline still quite slow and has not shown encouraging developments.

Legal politic has been used by Moh. Mahfud M.D and Benny K Harman as an approach to understand relations between politics and law. From the scientific work both Mahfud and Harman try to present a different approach in understanding a legal phenomenon. In this case differs from the classical approach that viewed the law of the normative, Mahfud and Harman saw the laws of the socio-political, namely to bring the political system as the variables that affect the formula and the implementation of the law. Based on the results of Mahfud's research, concluded that political regime's process and configuration would have very significant effect on a legal product which its later emerge to.

In democratic states political configuration, the legal product is populist responsive character, whereas in states which configuration authoritarian political, legal product is characterized orthodox or conservative or elites.

Independent Variable Dependent Variable

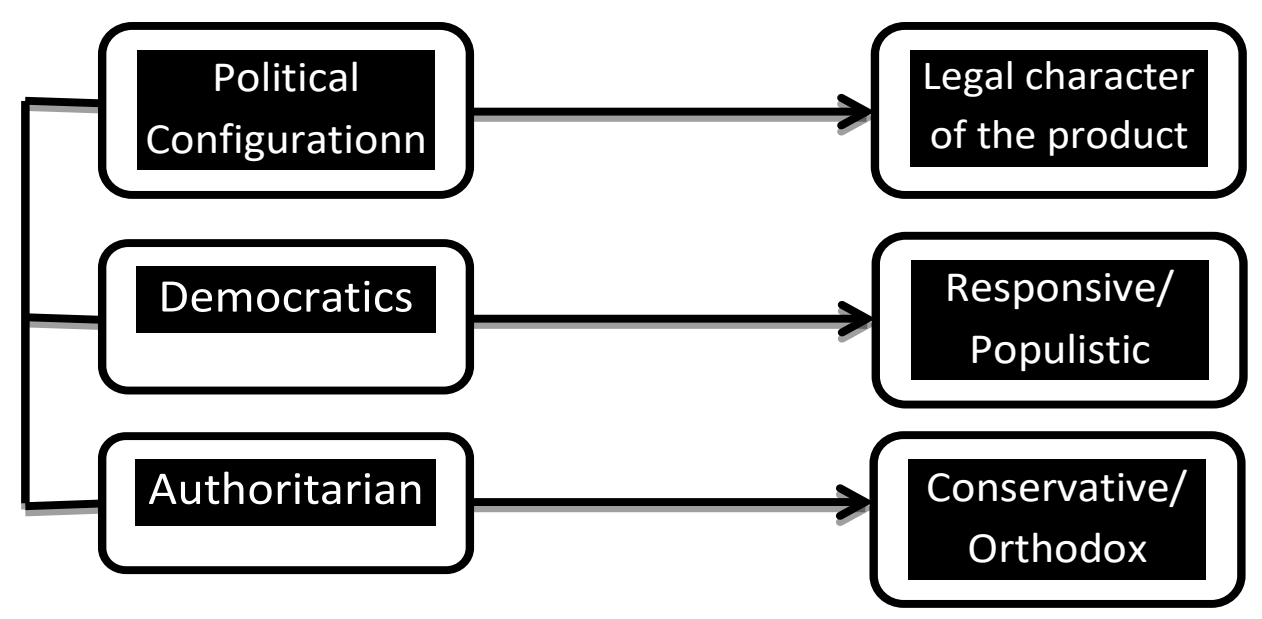

Picture 1

The political relations and character of legal products according to Mahfud M.D

"According to Benny K Harman, when the democratic states political configuration applied, the character of the judicial power that results from such a political configuration is the character of an independent and autonomous judicial power, which is autonomous or dependent." 
Independent Variable Dependent Variable

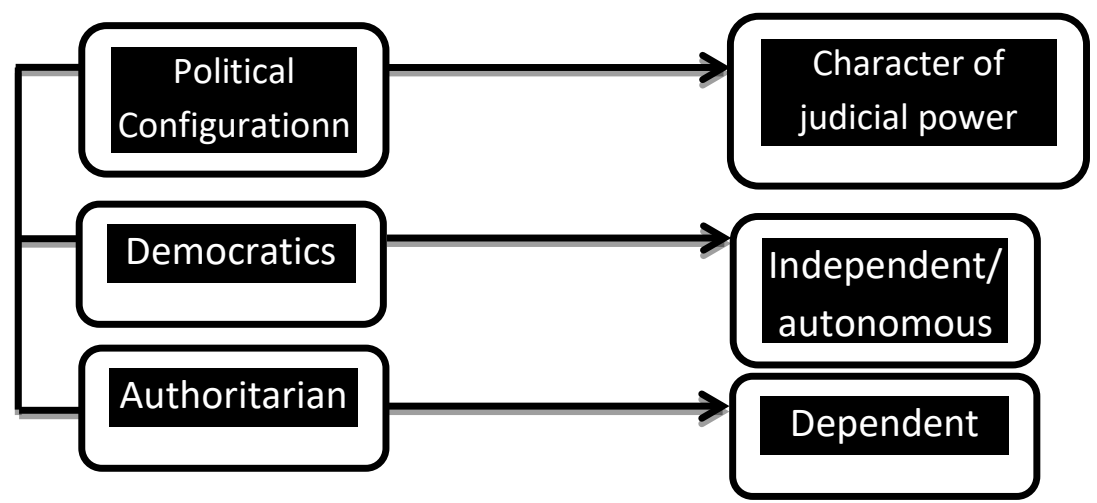

Picture 2

The relation of Politics and judicial power according to Benny K Harman. ${ }^{1}$

When examined closely, Mahfud and Harman use the same assumption, there is close relationship between law and politics but the object of research is different. Mahfud more emphasized on the aspects of the relationship between political configuration and the character of legal products. Whereas Harman emphasis on aspects of the relationship between political configuration and the character of judicial power, whether it is autonomous or not autonomous. From the results of their research, they both argue that political conflict was greatly influences the character of legal products and the character of judicial power

Mahfud in his book stated clearly that the research model he was done of law rather than politics, based on the argument that legal politics was part of legal science rather than political science. He explained, when legal science was likened to a tree, philosophy was the root while politics was the trunk which then gave birth to branches in various fields of law such as civil law, criminal law, constitutional law, state administrative law, etc. ${ }^{2}$ Then the issue of concern is the Form of Political Intervention Against Legislation in Indonesia.

\section{METHOD}

This study using normative legal research methods or library research methods which are conducted by examining existing library materials. ${ }^{3}$ The approach using is the statute approach.

The legal material used is Primary Legal Material, which is legal material consisting of Legislation. Secondary Legal Material is legal material that provides an explanation of primary legal materials, including research results, textbooks, scientific journals, newspapers, and internet. Tertiary Legal Materials are legal materials that can explain both primary and secondary legal materials, in the form of dictionaries (legal dictionaries and Language dictionaries)

\section{ANALYSIS AND DISCUSSION}

\section{Legal and Public Life Changes}

Indonesia legal scholars diverse that legal term used in Indonesia to use or adopt from Netherlands, as the State administration law (staatrecht), private law (privaatrecht), criminal

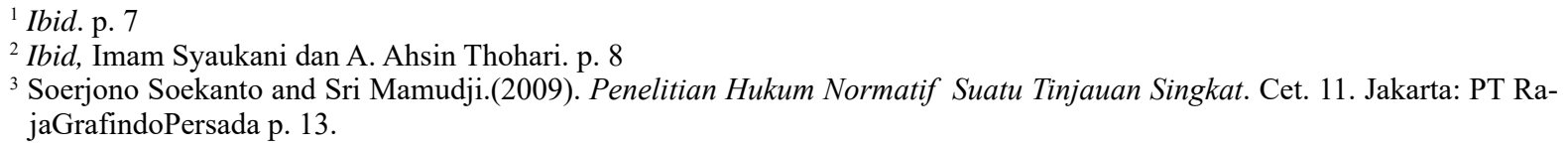


law (straafrecht), and administrative law (Administratiefrecht $)^{4}$. The politics law is part of the science of law that examines changes in ius constitutum to become ius constituandum to meet changes in people's lives. Understand the people's changes lives needs explored whether the notion of change, understanding of life and understanding of society. ${ }^{5}$

Factors that affect changes in the life of a society can constitute factors that can be found in the community it self (internal factors) and can also be factors that come from outside (external factors). These internal factors eg human thinking members of the public concerned, then necessities of life concerned community members, and how members of the society concerned.

Changing in the area of community life can also affect to other areas of life. Example five areas of life, such as:

a. The legal field is the area of life that strives to meet the needs of an orderly and fair life;

b. Political field life is the area of life that seeks to find the needs of life in power in society;

c. Economic field life is the area of life that strives to meet the needs of physical life;

d. Social field life is the area of life that strives to meet the needs of life in togetherness;

e. Cultural field life is the area of life that meets the needs of a noble life. ${ }^{6}$

\section{Authority in The Enactment of Legislation}

Every authority of state institution/state official based on a source of authority especially Indonesia as a rule of law as stipulated in article 1 paragraph (3) of the 1945 Constitution. (1) protection of human rights, (2) distribution of power; (3) government based on law; (4) State administrative justice. ${ }^{7}$

\section{Configuration of Legislation Legal Politic}

The politics law in democratic states try give a chance to participation of the public to determine the pattern and content of the desired law. Indonesia based on Pancasila and the kinship will have its own legal politics accordance with the rechtsidee contained in Pancasila and the 1945 Constitution.

There are 3 levels of legislative political policy contained in the framework and paradigm of staatsidee or rechtsidee, such as: ${ }^{8}$

1. In the political order, the purpose of Indonesian law is to establishment of a democratic rule ofl aw.

2. In the social and economic order, legal politics aims at realizing social justice for all Indonesian people.

3. In the normative order, politics law aims to justice and truth in every facet of people's lives. These objectives are in the level of national law sourced, Pancasila and the 1945 Constitution.

\section{Global influencing}

The legal politic (now and in the future) should pay attention to global influences. In a global context, politics law cannot merely protect national interests, but also interest to developments that occur in international interests.

\footnotetext{
${ }^{4}$ Imam Syaukani and A. Ahsin Thorari.(2015).Dasar-dasar Politik Hukum. Cet. 10. Jakarta:PT Raja Grafindo Persada.p. 18.

${ }^{5}$ H. Abdul Latif dan Hasbi Ali.(2010). Politik Hukum, Cet. I. Jakarta Timur: Sinar Grafika .p. 51.

${ }^{6}$ Ibid, p. 53-54.

${ }^{7}$ Ahmad Redi. (2018). Hukum Pembentukan Peraturan Perundang-undangan., Cet. Pertama, Jakarta Timur: Sinar Grafika Offest .p. 38 .

${ }^{8}$ Op.Cit. p. 166.
} 
Like the legal politics regarding patents, it cannot be separated from the interests of those rights that are owned by foreigners. Notwithstanding these interests, not only does it contain legal conflicts but it may be political and economic conflicts among countries.

Recently there are three Patent Laws in Indonesia including Law No. 6 of 1998, Law No. 13 of 1997, and Law No. 14 of 2001 in force. If the reason for adjusting the provisions of the TRIPs is assessed from the content of the Law established, adjustments to TRIPs only include the classification of plant varieties as inventions that cannot be patented ${ }^{9}$ and also the exclusion of imports of patent infringement pharmaceutical products. ${ }^{10}$

The latest Patent Law establishing in line with the trade policy of developed countries. It is regarded as the government's seriousness improving intellectual property rights protection in Indonesia. In this regard, Indonesia should establish a patent system and strive to provide legal protection as well as possible, because it is part of the investment climate desired by foreign parties. $^{11}$

\section{Foreign intervention in the formation of legislation in Indonesia}

Legislation in every country made by people with basic thoughts, these basic thoughts can influenced by factors such as ideological or religious beliefs, experience, knowledge and also interests such as personal, group or party interests, people's interests or foreign interests.

According to Abdul Latif and Hasbi Ali in the book Politics of law, that interventions in the formation of legislation in Indonesia have many foreign interventions, these foreign interventions can be categorized from government to government and Interventions of nongovernment). ${ }^{12}$ Some legislation that got foreign intervention, namely the Law on Terrorism, the Law on the Elimination of Domestic Violence (Domestic Violence Act), and the Rejection of the Anti-Pornography and Pornography Act.

Abdul Latif and Hasbi Ali in their book said that the Law No. 5 of 2018 on Eradication the Criminal Acts of Terrorism there was foreign government intervention, a statement made by the USA, Australia and Singapore that Indonesia was a terrorist nest. As happened in Indonesia in 2001 on August $1^{\text {st }}$. The bomb exploded at the Atrium Plaza in Senen, which resulted in 3 (three) injured by Taufik Bin Abdullah alias Halin, a Malaysian citizen. Then in October $1^{\text {st } 2015}$, bombs exploded again in Bali, precisely in Jembaran Biac Resort Kuta 22 peoples were killed and 102 peoples were injured by Anip Solehanudin alias Pendek Bin Suyadi. ${ }^{13}$

Since the terror attacks that began with the chain attack 3 (three) Church in Surabaya, this Act was establish because of pressure from massive as Indonesia along with Malaysia and the Philippines trilateral meeting to enhance cooperation in handle of threat of terrorism and extremism. It was attended by Indonesian Foreign Minister Retno Marsudi, Malaysian Foreign Minister Dato 'Sri Anifah Hj Aman and Philippine Foreign Secretary Alan Peter S Cayetano. The meeting was held in Manila, Philippines ${ }^{14}$. In this law agreed that acts which can classify as terrorism are crimes with violence or threats of violence.

Abdul Latif and Hasbi Ali also said that in Law No. 23 of 2004 concerning the Elimination of Domestic Violence. In connection with the many cases of violence, especially in the

\footnotetext{
${ }^{9}$ Article 7 Act Number 14 Year Concerning Patent.

${ }^{10}$ Ibid, Article 135

${ }^{11} \mathrm{http} / / /$ media.neliti.com [accessed September 27, 2019]. See also Zen. Umar Urba. (2015). Hak Kekayaan Intlektual Pasca TRIPs. Bandung: Alumni p. 84-96

${ }^{12}$ H. Abdul Latif and Hasbi Ali. (2010). Politik Hukum, Cet. I. Jakarta Timur: Sinar Grafika.p. 168

${ }^{13}$ http://ejounar-s1.Undip.ac id/index.pht/jihi.Journal Of International Relasion, Volume 2, Nomor 4, Tahun 2016.p 61.[Accsesed at January 18, 2019].

${ }^{14}$ https://m.detik.com/news/berita/d-3539922/indonesia-malaysia-dan-filipina-sepakati-15-poin-kontra-terorisme [accesed at January 26, 2019].
} 
household, the emerge of the law on the elimination of domestic violence is one of the historical milestones for the protection of victims of domestic violence that occur within the domestic scope, especially women and children as a group vulnerable to becoming victims of violence. ${ }^{15}$

Domestic violence is also defined as a form of discrimination, in Convention on the Eliminations of All Forms of Discrimination Against Women (CEDAW). Convention against torture, inhuman and degrading treatment or punishment (resolution number 39/46, approved by the UN general assembly on December 10, 1984.

The foreign intervention in question, the non indication and can not be ascertained. Whether or not it is right after the intervention "produces" the formalization of what has become the foreign agenda, and the articles then become the basis forforeig nactivities which are detrimental to the people at large and are contrary to ideology or religion for the Indonesian people. Thus, it can said that foreign intervention through the Law is detrimental to the nation'swidespread and beneficial to the state-ForeignCountries.

\section{CONCLUSION}

The form of intervention from the establish of the legislation is carried out in a direct or veiled manner by both foreign and non-governmental organizations (NGOs) funded by foreigners. Therefore, it becomes important to watch out for any intervention in the formation of laws and laws in Indonesia and not always easy to get evidence of foreign intervention in the legislative process

\section{BIBLIOGRAPHY}

Books:

Abdul Latif dan Ali Hasbi. (2010). Politik Hukum. Cet. I, Jakarta Timur. Sinar Grafika.

Ahmad Redi. (2018). Hukum Pembentukan Peraturan Perundang-undangan, Cetakan Pertama, Jakarta: Sinar Grafika.

Imam Syaukani and A Ahsin Thohari. (2015). Dasar-dasar Politik Hukum, Cetakan ke-10, Jakarta: Raja Grafindo Persada.

M Fakih. (1998). "Diskriminasi dan Beban Kerja Perempuan: Perspektif Jender". Hj Bainar, Wacana Perempuan Dalam Keindonesiaan. Pustaka CIDESINDO

Moh Mahfud MD. (2007). Politik Hukum di Indonesia, Cetakan ke-7. Jakarta: Pt Raja Grafindo.

Munti, Batar, Ratna. (2005). Lahirnya UU Penghapusan Kekerasan Dalam Rumah Tangga

Sebuah Bentuk Terobosan Hukum Dan Implikasinya Terhadap Hukum Nasional, edisi ke-2,LBH APIK Jakarata.

Ridwan. (2006). Kekerasan Berbasis Jender (Rekontruksi Teologis, Yuridis,dan Sosiologis), Pusat Studi Jender (PSJ) Purwokerto.

Sri Mamuji and Soerjono Soekanto. (2009).Penelitian Hukum Normatif Suatu Tinjauan Singkat, Cet. 11. Jakarta: Raja Grafindo Persada.

Legislation:

The Law No 14 Tahun 2001 Regarding Patent

The Law No. 22 of 2001 Regarding Oil and Gas ${ }_{15}^{15}$ Ridwan. (2006). Kekerasan Berbasis Jender (Rekontruksi Teologis, Yuridis, dan Sosiologis). Purwokerto: Pusat Studi Jender
(PSJ), p. 80.

76 Muhammad Satria, Munajah, Sulistia Ningsih Rahayu \& Suryadi | Political Intervention... 
The Law No. 13 of 2003 Regarding Employment

Minister of Education and Culture Decree No.002/U/1996

Presidential Regulation No 202018

World Wide Web:

http://ejounar-s1.Undip.ac id/index.pht/jihi.Journal Of International Relasion, Volume 2, Nomor 4, Tahun 2016. [Accessed January 18, 2019].

http://lifestyle.compas.com.sembilan-LSM-di-Belu-Tolak-RUU-ponografi.

[Accessed January 18, 2019].

https://m.detik.com/news/berita/d-3539922/indonesia-malaysia-dan-filipina-sepakati-15poin-kontra-terorisme. [Accessed May 16, 2019]. 